\title{
Economies of Scale and Cost Efficiency in Small Scale Egusi Melon Production in Bida Local Government Area of Niger State, Nigeria
}

\author{
Sadiq, M.S.*, Mohammed Abubakar And T.L.Yusuf.* \\ Department of Agric. Economics and Extension Techn., Federal University of Tech., Minna, Nigeria. \\ Author for correspondence
}

\begin{abstract}
This study shows empirical findings of economies of scale and cost efficiency of small scale egusi melon production in Niger State, Nigeria, using multi-stage random sampling techniques to elicit data from 125 respondents in the study area. Findings indicates that there is relative presence of economies of scale among the respondents; an average farm in the study area produce at a minimum cost considering the size of the farm which is an indication that they operates in stage II of production surface which is an efficient stage of resource utilization. Findings were further collaborated by mean cost efficiency of 1.165 which shows that an average farm in the study area is about $17 \%$ above the frontier cost, indicating that they are relatively efficient in allocating their scarce resources. The significance of the estimated gamma coefficient (0.65) indicate the presence of cost inefficiency effects in egusi melon production
\end{abstract}

Keywords: Cost efficiency; stochastic frontier cost function; economies of scale; small scale; Egusi melon; Niger state

\section{Introduction}

Egusi Melon (Colocynthis Citrullus L.) is a herbaceous annual vegetable with trailing hairy, ridge vine which bear tendrils and lobed leaves on long petioles that belong to the Cucurbitacesae family (Agba $e t$ al.,2009). The origin of the crop is Africa where it is cultivated in mixed cropping system with other crops

like yams and cassava in peasant farms ; in traditional farming systems egusi Melon canopy is use to control weed and run offs in newly cultivated plots (Agba, 2004). Olufemi and Salami (2006) stated that, egusi is easily identifiable with the complex traditional mixed cropping systems of the humid and sub-humid tropical zone of Nigeria, as the trailing nature of its vines, alternately arranged and pinnately dissected leaves allow interplanting at distances dictated by the number, sequence, type and combination of crops in the mixture.

The main harvested produce is the seed commonly consumed in Nigeria as a thickening for sauces and soups; also fry and eaten as snack (Agba et al., 2009); egusi melon seeds are popular condiments in Nigerian local soups. Melon seed is a good source of oil, protein, minerals, vitamins, and energy in form of carbohydrates. The seed contained $4.6 \mathrm{~g}$ carbohydrates, $0.6 \mathrm{~g}$ proteins, $0.6 \mathrm{~g}$ crude fibre, $33 \mathrm{mg}$ vitamin $\mathrm{C}, 17 \mathrm{~g} \mathrm{Ca}$, $16 \mathrm{mg} \mathrm{P}$ and $230 \mathrm{mg} \mathrm{K}$ per $100 \mathrm{~g}$ edible seeds (Olaniyi.,2008). Valuable vegetable oil is extracted from the seed while the ground seed is used to prepare various delicacies (Yusuf et al., 2008). In the Republic of Benin, Farmers' reported the medicinal role of some 'egusi' species such as C. lanatus subsp. mucosospermus. The sliced young fruit of this specie is said to heal stomach aches while the seed coat in decoction with Eucalyptus (Eucalyptus camaldulensis Dehnh.) roots is a sedative for epilepsy. The roasted seeds, ground with salt are taken with warm water or porridge to prevent vomiting (Ugwumba, 2010). According to Schippers (2000), egusi melon is important for their seeds in Sudan and Ethiopia and the Extracted yellow oil in high demand.

Cultivation of egusi as a sole crop is, however, becoming widespread, which with the mixed cropping production systems would ensure the 4.5\% annual growth in egusi seed output in 1990-2005, thus satisfying the demands of human dietary consumption and raw materials for the industrial processing to edible oil and livestock feedstuff. The strategies involved area expansion and increased productivity per unit of input from the medium and large-scale farms being encouraged in the humid to sub-humid agro-ecological zones of Nigeria, whose bimodal rainfall pattern allows successful cultivation in the early and late seasons (Olufemi et al., 2006). Inspite of its economic importance, egusi melon has not received much attention from scientific researchers. The production of 'egusi' melon is declining in the study area, even though that the crop plays many vital socio-economic and cultural roles in the wellbeing of the farmers' and communities in its entirety. Since there is no documented study on cost efficiency of egusi melon production in the area, this study therefore became imperative. Findings from these study would aid in policy advocacy, thus in sustainable and improved production of the crop. 
Theoretical Framework: Farrell (1957) distinguishes between technical and allocative efficiency (or price efficiency) as a measure of production efficiency through the use of a frontier production and cost function respectively. He defined technical efficiency as the ability of a firm to produce a given level output with a minimum quantity of inputs under certain technology and allocative efficiency as ability of a firm to choose optimal input levels for a given factor prices.

In Farrell's framework, economic efficiency (EE) is an overall performance measure and is equal to the product of TE and $\mathrm{AE}$ (That is $\mathrm{EE}=\mathrm{TE} * \mathrm{AE}$ ). However, over the years, Farrell's methodology had been applied widely, while it undergoes many refinement and improvement. Such improvement is the development of stochastic frontier model that enables one to measure firm level efficiency using maximum likelihood estimate. The stochastic frontier model incorporates a composed error structure with a two sided symmetry and one sided component. The one sided component reflects inefficiency while the two sided component capture random effects outside the control of production unit including measurement errors and other statistical noise typical of empirical relationship.

Economic application of stochastic frontier model for efficiency analysis include Aigner et al (1977) in which the model was applied to U.S. agricultural data. Battese and Corra (1977) applied the technique to the pastoral zone of eastern Australia. More recently, Ogundari and Ojo (2005), Ojo (2004). Ajibefun et al. (2002), Bravo-Ureta and Pinheiro (1993) and Ali and Byerlee (1991) in which they offer a comprehensive review of the application of the stochastic frontier model in measuring of agricultural producers in developing countries.

The production technology can be represented inform of cost of function. The cost function represents the dual approach in that technology is seen as a constant towards the optimizing behavior of firms (Chambers, 1983). In the context of cost function any error of optimization is taken to translate into higher cost for the producers.

However, the stochastic nature of the production frontier would still imply that the theoretical minimum cost frontier would be stochastic. The cost function can be used to simultaneously predict both technical and allocative efficiency of a firm (Coelli, 1995). Also, it can be used to resurrect all the economically relevant information about farm level technology as it is generally positive, non-decreasing, concave, continuous and homogenous to degree one to one input prices (Chambers, 1983).

Scale Effect (SE) is mathematically defined as inverse of the sum of all cost elasticities with respect to all output included in the regression. The cost function parameter estimated most especially the coefficients of the output for the Cobb-Douglas model suggests the presence of scale effects (SE) in the production process. Positive economies of scale (ESp) prevail, if the SE is greater than 1 (ESp is defined as the reduction in cost of production of the given output level while holding all other input prices constant) and, conversely, the diseconomies of scale (DS) when the SE is less than 1. The return-to-scale and scale effects are equivalent measures if and only if the product is homothetic, an assumption that applies to and is implicit in the CobbDouglas function structures (Chambers 1988). If costs increase proportionately with output, there are no economies of scale meaning that there is a constant return-to-scale. If costs increase by a greater amount than output, there are diseconomies of scale meaning that there is a decreasing return-to-scale if costs increase by a lesser amount than the output, there are positive economies of scale which is sometimes referred to simply as economies of scale meaning increasing return-to-scale. Here, since the Cobb-Douglas function was used, this assumption is imposed.

\section{Research Methodology}

Study area: The study area is Niger State of Nigeria. The State is located in North-central Nigeria between Latitudes $8^{\circ} 20^{\prime} \mathrm{N}$ and $11^{\circ} 30^{\prime} \mathrm{N}$ and Longitudes $3^{\circ} 30^{\prime} \mathrm{E}$ and $7^{\circ} 20^{\prime} \mathrm{E}$ with a total land area of 76,363 square kilometres and a population of 4,082,558 people (Wikipedia, 2008). Agriculture is the predominant source of livelihood with small scale traditional farming system predominant in the area. The State is well suited for production of a wide variety of crops such as yam, cassava, maize, millet, rice, cowpea, egusi melon, etc because of the favourable climatic condition. Annual rainfall is between $1100 \mathrm{~mm}$ and $1600 \mathrm{~mm}$ with average monthly temperature hovering around $23^{\circ} \mathrm{C}$ to $37^{\circ} \mathrm{C}$ (NSADP, 1994). The vegetation consists mainly of short grasses, shrubs and scattered trees. The range of local climatic and soil conditions, resource availability, and markets allows a wide variety of cereal, pulse and tuber crops to be grown.

Sampling Size and Technique: The sampling frame for this study comprised of all the egusi melon farmers in Bida LGA of Niger State. The data used for this study were mainly from primary sources collected from farmers who were selected using multi-stage random sampling techniques. Bida LGA was taken as the sampling unit as first stage of sampling. In the second stage, five villages were randomly selected from the LGA. The last stage involved random selection of twenty five (25) egusi melon farmers in each village bringing the total 
sample size to 125 respondents. Data were collected with the use of a structured questionnaire to collect inputoutput data of the farmers. Data collected was analyzed using stochastic frontier cost function model.

\section{Model specification}

In this study, Battese and Coelli (1995) model was used to specify a stochastic frontier cost function with behaviour inefficiency component and to estimate all parameters together in one step maximum likelihood estimation. This model is implicitly expressed as:

In $\mathrm{C}=\mathrm{f}(\mathrm{Pi}, \mathrm{Yi} ; \alpha)+(\mathrm{Vi}+\mathrm{Ui})$

Where;

$\mathrm{Ci}=$ Total production cost;

$\mathrm{f}=$ Functional form such as Cobb-Douglas;

$\mathrm{Pi}=$ Vector variable of input prices (labour, fertilizer, seeds, annual depreciation cost of farm tools and pesticides); and,

$\mathrm{Yi}=$ Value of egusi produced $(\mathrm{kg})$.

$\alpha=$ is the parameters to be estimated.

The systematic component, $V_{i}$ represents random disturbance costs due to factors outside the scope farmers. It is assumed to be identically and normally distributed mean zero and constant variance as $\mathrm{N}\left(0, \sigma^{2} \mathrm{v}\right)$. Ui is the one sided disturbance form used to represent cost inefficiency and is independent of $\mathrm{Vi}$. Thus, $\mathrm{Ui}=0$ for a farm whose costs lie on the frontier, $\mathrm{U}_{\mathrm{i}}>0$ for farms whose cost is above the frontier and $\mathrm{Ui}<0$ for farm identically and independently distributed as $\mathrm{N}\left(0, \sigma^{2} \mathrm{u}\right.$.). The two error terms are proceeded by positive signs because inefficiencies are always assumed to increase cost.

Moreover, for the study the cost efficiency of an individual farm is defined in terms of the ratio of observed cost $(\mathrm{Cb})$ to the corresponding minimum cost $(\mathrm{Cmin})$ given the available technology. That is: Cost Efficiency (CEE) $\underline{\mathrm{Cb}}=\underline{\mathrm{f}}\left(\mathrm{P}_{\mathrm{i}}, \mathrm{Y}_{\mathrm{i}} ; \alpha\right)+\left(\mathrm{V}_{\mathrm{i}}+\mathrm{U}_{\mathrm{i}}\right)=\exp \left(\mathrm{U}_{\mathrm{i}}\right)$

$\mathrm{Cmin} \quad \mathrm{f}\left(\mathrm{P}_{\mathrm{i}}, \mathrm{Y}_{\mathrm{i}} ; \alpha\right)+\left(\mathrm{V}_{\mathrm{i}}\right)$

Where the observed cost $(\mathrm{Cb})$ represents the actual total production cost while the minimum cost $(\mathrm{Cmin})$ represents the frontier total production cost or least total production cost level.CEE takes value of 1 or higher with 1 defining cost efficient farm. Following the adoption of Battese and Coelli (1995) framework for the analysis of the data, the explicit Cobb-Douglas functional form for the egusi farms in the study area is therefore specified as follows:

In $\mathrm{C}=\alpha_{0}+\alpha_{1} \operatorname{InP}_{1}+\alpha_{2} \operatorname{InP}_{2}+\alpha_{3} \operatorname{InP}_{3}+\alpha_{4} \operatorname{InP}_{4}+\alpha_{5} \operatorname{InP} P_{5}+\alpha_{6} \operatorname{InY}+(\mathrm{Vi}+\mathrm{Ui})$

Where:

$\mathrm{C}=$ Total production cost in naira $(\mathrm{N})$;

$\mathrm{P}_{1}=$ Cost of labour $(\mathrm{N})$;

$\mathrm{P}_{2}=$ Cost of fertilizer $(\mathrm{N})$;

$\mathrm{P}_{3}=$ Cost of seed $(\mathrm{N})$

$\mathrm{P}_{4}=$ Annual depreciation cost of farm tools $(\mathrm{N})$; and,

$\mathrm{P}_{5}=$ cost of pesticides $(\mathrm{N})$; and,

$\mathrm{Y}_{\mathrm{i}}=$ Output of egusi in (kg).

The choice of the Cobb-Douglas is based on the fact that the methodology requires that the function be self dual as in the case of cost function in which this analysis is based on.

The inefficiency model (Ui) is defined by:

$\mathrm{U}_{\mathrm{i}}=\delta_{0}+\delta_{1} \mathrm{Z}_{1} \mathrm{i}+\delta_{2} \mathrm{Z}_{2} \mathrm{i}+\delta_{3} \mathrm{Z}_{3} \mathrm{i}+\delta_{4} \mathrm{Z}_{4} \mathrm{i}+\delta_{4} \mathrm{Z}_{4} \mathrm{i}$

Where $Z_{1}, Z_{2}, Z_{3}, Z_{4}$ and $Z_{5}$ represent age, educational level, household size and farming experience. These socioeconomic variables are included in the model to indicate their possible influence on the cost efficiency of the farmers. The $\alpha$ and $\delta$ are scalar parameters to be estimated. The variance of the random error, $\sigma^{2} \mathrm{v}$ and that of the cost inefficiency effects $\sigma^{2} u$ and the overall variance of the model $\sigma^{2}$ are related as follows: $\gamma^{2}=\sigma^{2} u / \sigma^{2} v+$ $\sigma^{2}$ u. The gamma $(\gamma)$ measures the total variation of total cost of production from the frontier cost which can be attributed to cost inefficiency (Battese and Corra, 1977). The estimate for all the parameters of the stochastic frontier cost function and the inefficiency model are simultaneously obtained using the program FRONTIER version 4.1c (Coelli, 1996).

\section{Result and Discussion}

Maximum-likelihood estimates of the parameters of the stochastic cost frontier model are presented in Table 1. The estimated gamma parameter $(\gamma)$ was 0.65 and highly significant at $1 \%$ level, thus indicating that about $65 \%$ of the variation in the total cost of production among the sample farmers was due to differences in their cost efficiencies. Furthermore, the presence one sided error, indicate that traditional response function (OLS) is not an adequate representation of the data. 
All parameters estimated carried the expected sign with cost of labour, cost of seed, annual depreciation cost, cost and maize output highly significant at $1 \%$, except the cost of pesticides, hence, important in egusi melon production. The cost elasticities with respect to all input variables use in the production analysis are positive and imply that an increase in the cost of labour, cost of fertilizer, cost of seed, annual depreciation cost, cost of pesticides and production (egusi output in $\mathrm{kg}$ ) increases total production cost. That is $1 \%$ increase in the cost of labour will increase total production cost by approximately $0.1 \% ; 1 \%$ increase in the cost of fertilizer will increase total production cost by approximately $0.1 \% ; 1 \%$ increase in the cost of seed will increase total production cost by approximately $0.1 \% ; 1 \%$ increase in the annual depreciation cost will increase total production cost by approximately $0.1 \% ; 1 \%$ increase in the cost of pesticides will increase total production cost by approximately $0.1 \%$; and $1 \%$ increase in the egusi melon output will increase total production cost by approximately $0.8 \%$. However, all independent variables confirm with a prior expectation as all the estimated coefficients of the costs gave the positive coefficients indicating the conformity with the assumption that the cost function monotonically increases with the input prices.

The scale effect among the egusi melon farms in the study area was computed as the inverse coefficient of cost elasticities with respect to the egusi melon output in $\mathrm{kg}$ as the only output in the analysis shows scale effects among the sampled farmers. This is because the computed value of the SE is 1.22 (i.e., $1 / 0.820=1.22$ ) which confirms that there is a positive economies of scale. The computed value of the SE is greater than one, meaning that $1 \%$ increase in the total production costs increased the total egusi melon production by $1.22 \%$ during the course of production. The economic implication of this value is that the sample farms despite being small scale in nature expand their production capacities in order to decrease their cost to the lowest minimum in course of production irrespective of their size of operation which shows that the farms are experiencing decreasing but positive return to scale (stage II of production surface), since return to scale and economies of scale are equivalent measures. However, this result is in conformity with the earlier findings under the analysis of the inefficiency model. According to Reddy et al. (2004), the stage I of production can be regarded as the sub-optimal stage where the fixed resources are abundant relative to the variable resources.

The analysis of the inefficiency model is depicted in the Table 1 . The explanatory variables in the model show that the signs and significance of the estimated coefficients in the inefficiency model have important implications on the cost efficiency of the egusi melon production in the study area. The positive coefficient of the age of farmer's implies that farmers of older age tend to be less cost efficient. This is in conformity with the assumption that farmers' age affects the production efficiency since farmers of different ages have different levels of experience ability to obtain and process information. The negative coefficient for household size implies that cost efficiency increases with the increase in family size. This is due to the fact that the farmers with lager household size rely on readily cheap available family labour, subsequently reducing the cost inefficiency in egusi melon production in the study area. Similarly, the negative and significant coefficient for the education implies that cost inefficiency decrease with increase in farmer's education. This relation indicates that educated farmers' are more economically efficient. Education enhances the knowledge, skill and attitude to adopt the more efficient technology and to allocate the inputs of production of the farms more efficiently. The negative coefficient for farming experience implies that experience reduces cost inefficiency. The negative coefficient for extension contact implies that access to extension service reduces cost inefficiency. This may be as a result of adoption of improved farm practises

Table 1: Maximum-likelihood estimates of parameters of the Cobb-Douglas frontier function for small scale egusi melon farmers

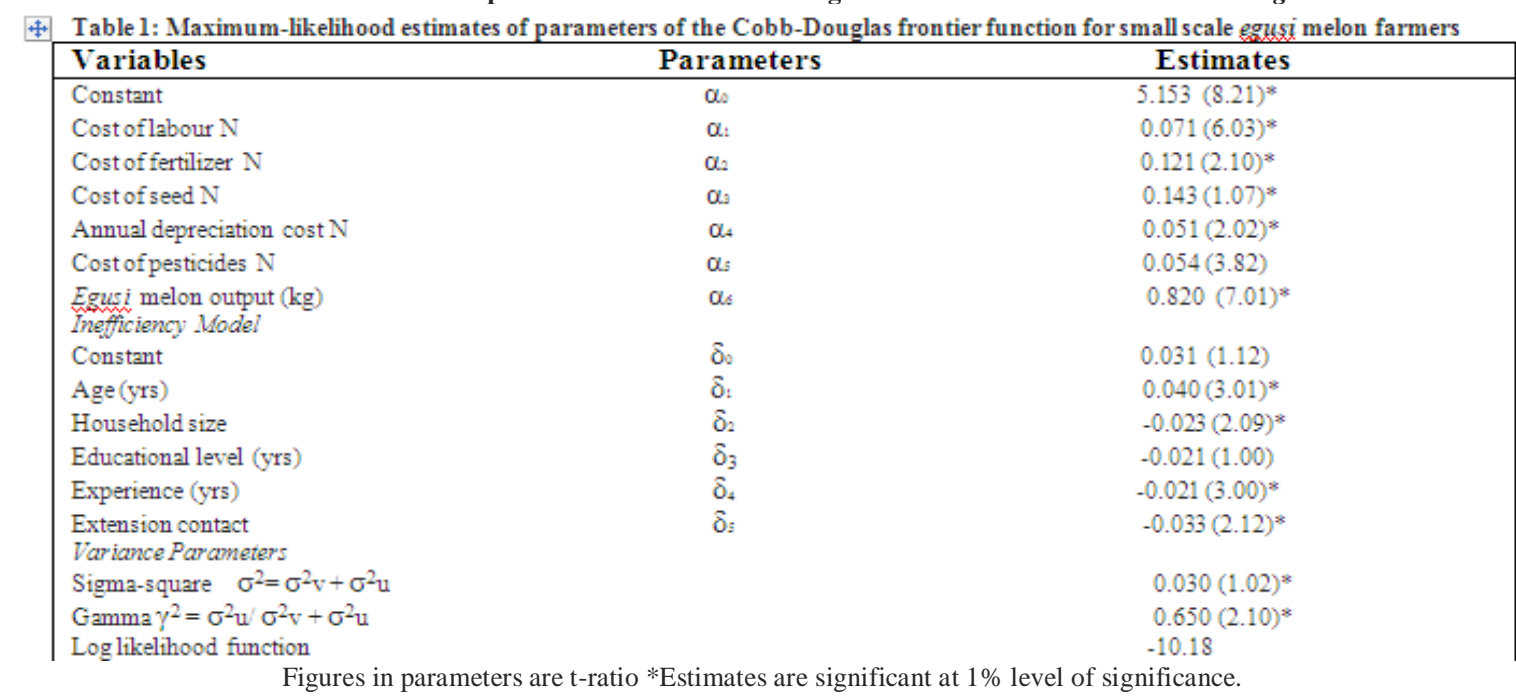


Result in Table 2 shows cost efficiency scores for the egusi melon farms in the study area. Cost efficiency is estimated as $\mathrm{CEE}=\exp (\mathrm{U} i)$. The predicted cost efficiencies (CEE) ranged from 1.0 to 5.2. The mean cost efficiency of the farms was 1.165; meaning that an average egusi farm in the sample area has costs that are about $17 \%$ above the minimum defined by the frontier. In other words, $17 \%$ of their costs are wasted relative to the best practiced farms producing the same output and facing the same technology.

The higher the value of CEE, the more inefficient the farm is. However, the frequencies of occurrence of the predicted cost efficiency between 1.0 and 1.1 representing about $82 \%$ of the sampled farmers, implying that majority of the farmers' are fairly efficient in producing at the given level of output using the cost minimizing input ratios which reflects the farmers' tendency to minimize resource wastage associated with production process from cost perspective. This agrees with Dia et al. (2010), who reported that, relatively larger proportion of small scale maize farms were fairly efficient in minimizing resource wastages associated with production process.

Table 2: Cost efficiencies level of small scale Egusi farmers

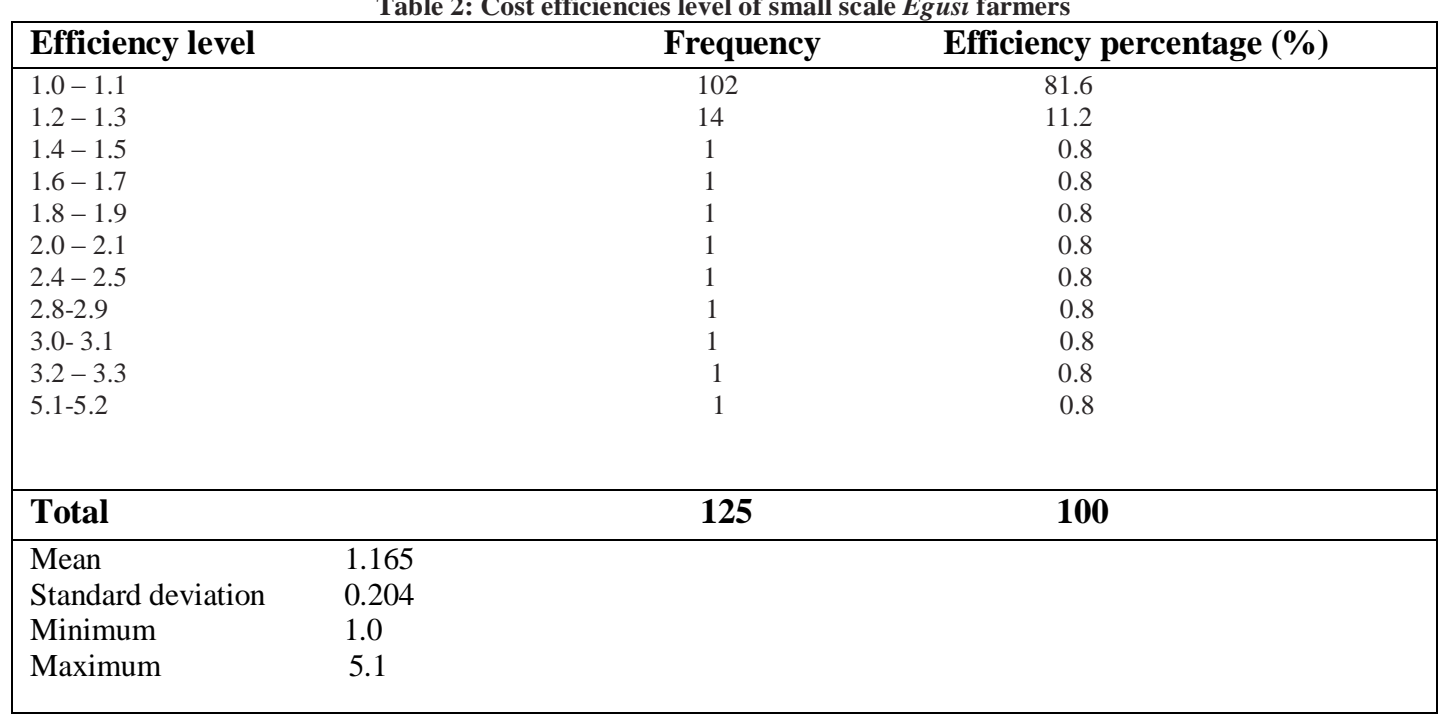

\section{Summary, Conclusion and Recommendation}

This empirical study is on economies of scale and cost efficiency in small scale egusi melon production using stochastic frontier cost function. A Cobb-Douglas functional form was used to impose the assumption that return to scale and economies of scale are equivalent measures if and only if the production function is homothetic. Empirical evidence indicates the existence of relative economies of scale despite the small scale level of the farms; the computed overall economies of scale is slightly above one, which indicates that the small scale egusi farmers are currently expanding their present level of production, which in the long run will enable them to experience decrease in the cost of production per output. Furthermore, the outcome of this result show that about $82 \%$ of the farms included in the sample operates close to the frontier level, achieving scores of about $17 \%$ or lower in terms of cost difference in the relation for the best-practiced technology. However, the level of the observed cost efficiency has been shown to be significantly influenced by household size, education, farming experiences and extension contact. In conclusion, the relative closeness of the computed overall economies of scale $(\boldsymbol{S E})$ of 1.22 and an average cost efficiency $\left(\mathrm{C}_{\mathrm{EE}}\right)$ of 1.165 from unity, is an indication they are fairly efficient in the use of their resources even though they are small scale holders; and any expansion in their present level of production would reduce the cost of production per output. The prevailing but fairly economies of scale obtained for the study is in accordance with results of Dia et al. (2010) that indicate higher relative efficiency for small farms. Useful policy recommendations made by agricultural researchers should be implemented by the government, thereby, helping the farmers to make better farm strategies in the future so as to increase output as well as profit; contributing towards the achievement of self sufficiency in the nation.

\section{References}

[1]. Agba, O.A (2004). Effect of Nitrogen and Phosphorus on the growth and yield of Egusi (Colocynthis Citrillus L.) in Cross River State. Journal of Agriulture, Forestry and the social Science (JOAFSS). Vol.2. No.2: 1-7.

[2]. Agba, O.A., I.B. Adinya, E.A. Agbogo, M.A. Oniah, N. Tiku, Abam Prince and M. Lifu (2009). Responses of Egusi Melon (Colocynthis Citrollus L) To Poultry Manure In Obubra, Cross River, South-South Nigeria. Continental J. Agronomy 3: 13 - 18.

[3]. Aigner, D. I. C., A. K. Lovell and P. Schmidt (1977). Formation and Estimation of Stochastic frontier production function Models. Journal and Econometrics 6: $21-371$.

[4]. Ajibefun, I.A., G. E. Battese and A. G. Daramola (2002). Determinants of Technical Efficiency in Smallholder crops farming: Application of Stochastic Frontier production function. Quarterly Journal of International Agriculture, 41(3): 225 - 240. 
[5]. Ali, M. and D. Byerlee (1991). Economic Efficiency of Small Farmers in a Changing World: A Survey of Recent Evidence. Journal of Development Studies 4: 1 - 27

[6]. Battese, G.E. and G. S. Corra (1977). Estimation of a production Function Model with Application to thePictorial Zone of Eastern Australia. Australian Journal of Agricultural Economics, 21: 169 - 179.

[7]. Battese, G. E. and T. J. Coelli (1995). A Model for Technical Inefficiency Effects in Stochastic Frontier Production for Panel Data. Emperical Economics, 20: 325 - 345.

[8]. Bravo - Ureta, Boris E. and E. Antonio Pinheiro (1993). Efficiency Analysis of Developing Country Agriculture: A Review of the Frontier Function Literature. Agricultural and Resource Economics Review. 22(1): 88 - 101.

[9]. Chambers, R. G. (1983). Applied Production Analysis: A Dual Approach. Cambridge: Cambridge University Press.

[10]. Coelli, T. J. (1995). Recent Development in Frontier Modeling and Efficiency Measurement. Australian Journal of Agricultural Economics, 39: $219-245$.

[11]. Coelli, T .J.(1996). A Guide to Frontier version 4.1c: A computer Programme for Stochastic Frontier productionandCost Function Estimation. Mines, Dept. of Econometrics, Armidele, Australia:University of New England.

[12]. Dia Y. Z., J. W. Zalkuwi and O. Gwandi (2010). Economics of scale and cost efficiency in small scale maize production in Mubi North Local Government in Adamawa State, Nigeria. African Journal of Agricultural Research Vol. 5(19), pp. 2617-2623.

[13]. Farrell, J.M. (1957). The Measurement of Productive Efficiency. Journal Royal Statistics, 120, (Part III); 253 - 290.

[14]. Niger State Agricultural Development Programme (NSADP) (1994). Impact study final report, pp24

[15]. Ogundari, K. and S. O. Ojo (2005). The Determinants of Technical Efficiency in mixed Crop Food Production in Nigeria: A Stochastic Parametric Approach. Proceedings of the 1st Annual Conference on Developments in Agriculture and Biological Science, 21st April, 2005. School of Agriculture and Agricultural Technology, Federal University of Technology, Akure, Nigeria. Pp $159-164$.

[16]. Ojo, S .O. (2004). Improving Labour Productivity and Technical Efficiency in Food Crop Production. A Panacea for Poverty Reduction in Nigeria." Journal Food Agriculture and Environment, 2(2): 227- 230.

[17]. Olaniyi, J.O (2008). Growth and Seed Yield Response of Egusi Melon to Nitrogen and Phosphorus Fertilizers Application. American-Eurasian Journal of Sustainable Agriculture, 2(3): 255-260

[18]. Olufemi J. Ayodele and Ayodeji E. Salami (2006). Physiological response of two variants of egusi melon (Citrullus lanatus) to plant population density in a humid environment Journal of Food, Agriculture \& Environment Vol.4 (3\&4) : 110-113.

[19]. Reddy S.S., P.R. Ram, T.V.N.Sastry, I.B.DevI (2004). Agricultural Economics. Oxford and IBH PublishingCo. Pvt. Ltd., New Delhi, India.

[20]. Shippers R.R.(2000). African Indigenous Vegetables: An Overview of Cultivated Species, Natural Resources Institute, University of Greenwich. pp. 24-27.

[21]. Wikipedia (2008) Encyclopaedia, Retrieved, June10, 2008 from http://en.wikipedia.org/wiki/Niger

[22]. Yusuf O.S., A. Sanni, E.O. Ojuekaiye, O.O.Ugbabe (2008). Profitability of 'Egusi' Melon (Citrullus Lanatus Thunb.Mansf) Production under Sole and Mixed Cropping Systems in Kogi State, Nigeria. ARPN J Agric Bio Sc, 3: 14-18. 